\title{
STRATEGI OPTIMALISASI PENGGUNAAN INTERNET TERHADAP PENINGKATAN PRESTASI BELAJAR SISWA: STUDI KASUS SMA NEGERI 1 BURAU
}

\author{
Ahmad Ali Hakam Dani ${ }^{1}$ \\ ${ }^{1}$ Dosen Program Studi Teknik Informatika Universitas Andi Djemma Palopo \\ 1 ahmad.ali@ftunanda.ac.id
}

\begin{abstract}
Abstrak
SMA Negeri 1 Burau menyadari pentingnya penerapan penggunaan internet untuk meningkatkan prestasi belajar siswa agar sesuai dengan standar yang sekolah tentukan. Oleh karena itu, penggunaan internet yang optimal perlu dilakukan untuk memenuhi target yang sekolah tentukan. Penelitian ini merupakan jenis penelitian kualitatif, dengan menggunakan kerangka kerja system thinking dalam penyusunan strategi optimalisasi penggunaan internet di SMA Negeri 1 Burau. Penyusunan strategi optimalisasi menggunakan analisis SWOT, kemudian memetakan strategi-strategi yang diperoleh ke dalam tiga kategori, yaitu kategori berdasarkan pencapaian kinerja maksimal, kategori berdasarkan penggunaan biaya minimal, dan kategori berdasarkan kombinasi terbaik dari pencapaian kinerja dan penggunaan biaya. Hasil dari penelitian ini adalah strategi optimalisasi penggunaan internet yang sudah dikategorikan berdasarkan tiga kategori yang telah disebutkan sebelumnya, yang dapat dijadikan dasar atau acuan dalam model pembelajaran dengan menggunakan internet untuk meningkatkan prestasi belajar siswa dan meningkatkan mutu pendidikan di sekolah ini.
\end{abstract}

Kata kunci: Strategi, Optimalisasi, Penggunaan Internet, System Thinking.

\section{PENDAHULUAN}

Perkembangan teknologi saat ini berdampak kepada fenomena-fenomena yang terjadi di masyarakat dengan semakin banyaknya fasilitas-fasilitas yang menyediakan akses internet. Akses internet tersebut tidak hanya bisa ditemui pada pemerintahan, perkantoran, dan warung internet (warnet) namun sudah terdapat di sekolah-sekolah, perpusatkaan bahkan area-area publik yang telah memasang fasilitas wireless fidelity (wifi).

Kehadiran internet memudahkan masyarakat dalam mengakses informasi yang tersebar di seluruh dunia. Akses informasi ini dapat dimanfaatkan dalam berbagai bidang seperti ekonomi, politik, teknologi, sosial, dan lain-lain. Namun, informasi-informasi tersebut juga terdapat informasi yang tidak memberikan nilai manfaat bagi pengguna seperti pornografi dan perjudian.

Manfaat internet bagi pendidikan adalah dapat menjadi akses kepada sumber informasi, akses kepada narasumber, dan sebagai media kerja sama sehingga penggunaan internet yang intesif dan tepat guna akan mempunyai korelasi yang signifikan terhadap prestasi belajar siswa. Media belajar mampu membangkitkan minat dan motivasi siswa dalam belajar. Fasilitas internet sebagai penunjang kegiatan belajar mengajar di kalangan siswa sekolah menengah atas sudah mulai diterapkan.

Motivasi belajar yang tinggi akan mampu menunjang prestasi siswa. Selain itu, internet sebagai media belajar juga mampu merangsang kreativitas seseorang.

Hadirnya internet di sekolah, menjadi bukti bahwa kondisi pendidikan di Indonesia membutuhkan media informasi sebagai salah satu sumber ilmu pengetahuan.

Kurikulum pendidikan pun memasukkan materi penggunaan internet pada mata pelajaran Teknologi Informasi dan Komunikasi (TIK) laboratorium komputer yang terkoneksi dengan internet sebagai sarana penunjang mata pelajaran tersebut. Penggunaan internet sebagai media pembelajaran sudah mulai diaktifkan di SMA 
Negeri 1 Burau sejak Tahun Ajaran 2010/2011 yang didasari oleh kurikulum KTSP (Kurikulum Tingkat Satuan Pendidikan) tahun 2006 tentang penggunaan teknologi informasi dalam model pembelajara. Penggunaan internet dalam model pembelajaran diharapkan dapat menjadi salah satu cara atau metode dalam meningkatkan prestasi belajar siswa.

Tabel 1. Data Rata-Rata Nilai UN Siswa 3 Tahun Ajaran Terakhir

\begin{tabular}{|c|c|c|c|c|c|c|}
\hline \multirow{2}{*}{ Tahun Ajaran } & \multicolumn{4}{|c|}{ Rata-rata nilai UN } & \multicolumn{2}{c|}{$\begin{array}{c}\text { Siswa yang lulus di perguruan } \\
\text { tinggi negeri (\%) }\end{array}$} \\
\cline { 2 - 5 } & \multicolumn{2}{|c|}{ IPA } & \multicolumn{2}{c|}{ IPS } & \multirow{2}{*}{ Target } & Hasil \\
\cline { 2 - 5 } & Target & Hasil & Target & Hasil & & $13 \%$ \\
\hline $2010 / 2011$ & 8 & 7.03 & 8 & 7.08 & $20 \%$ & $25 \%$ \\
\hline $2011 / 2012$ & 8 & 7.91 & 8 & 7.38 & $30 \%$ & $25 \%$ \\
\hline $2012 / 2013$ & 8 & 6.51 & 8 & 6.38 & & \\
\hline
\end{tabular}

Berdasarkan tabel di atas, dapat dilihat pencapaian rata-rata nilai UN siswa 3 tahun ajaran terakhir atau sejak diberlakukannya penggunaan internet dalam model pembelajaran. Dari tabel dapat dilihat rata-rata nilai UN siswa belum mencapai target yang sekolah canangkan, dimana ada gap diantara target dan hasil yang diperoleh dari pencapaian rata-rata nilai UN tersebut. Masuknya internet sejak Tahun Ajaran 2010/2011 diharapkan dapat meningkatkan prestasi belajas siswa, akan tetapi kenyataannya, hasil yang diperoleh tidak sesuai dengan harapan atau target sekolah. Oleh karena itu, pada penelitian ini ditarik sebuah research question tentang permasalahan tersebut, yaitu bagaimanakah strategi optimalisasi penggunaan internet terhadap peningkatan prestasi belajar siswa?. Untuk menjawab pertanyaan penelitian tersebut, maka selanjutnya disusun tinjauan teoritis, analisis lingkungan sekolah, dan metodologi penelitian untuk menjawab permasalahan tersebut yaitu berupa pembuatan strategi optimalisasi penggunaan internet.

\section{TINJAUAN TEORITIS}

Penggunaan internet di era sekarang sudah menjadi hal biasa di beberapa kalangan. Bahkan, ada yang beranggapan penggunaan internet merupakan suatu kebutuhan sehari-hari yang harus dipenuhi. Internet merupakan hubungan antara berbagai jenis komputer dan jaringan di dunia yang berbeda sistem operasi maupun aplikasinya. Saat komputer saling beroperasi dengan komputer lain dalam sebuah kelompok, mereka menyusun sebuah jaringan. Internet adalah jaringan komputer raksasa yang terdiri dari ribuan jaringan yang lebih kecil lainnya di seluruh dunia (Ajie, 2008). Internet juga dapat dirumuskan sebagai sekumpulan besar komputer dalam suatu jaringan yang tergabung secara bersama-sama sehingga banyak pengguna dapat berbagi sumber daya mereka secara luas (Widiatmika, 2007). Di antara keseluruhan fasilitas internet terdapat lima aplikasi standar internet yaitu WWW (World Wide Web), Email (Electronic Mail), FTP (File Transfer Protocol), Newsgroup dan Mailing List,serta Search Engine (Isracezwendy, 2012). Menurut Horrigan (2002), terdapat dua hal mendasar yang perlu diamati untuk mengetahui intensitas penggunaan internet seseorang, yaitu frekuensi penggunaan dan lama penggunaan internet dalam setiap kali mengakses komputer.

Horrigan (2002) juga menggolongkan aktivitas-aktivitas internet yang dilakukan para pengguna internet menjadi empat bagian penting, yaitu Email, Fun Activities, Information Utility, dan Transactions. Sedangkan Quarterman dan Mitchell (1996) mengemukakan empat manfaat internet, yaitu Internet sebagai media 
komunikasi, sebagai media pertukaran data, sebagai media untuk mencari informasi atau data, dan manfaat sebagai sebuah komunitas. Kemudian Van Deursen dan Van Dijk (2009) menyatakan bahwa penggunaan internet itu berpengaruh terhadap kemampuan dan tingkah laku pengguna pengguna pada dunia maya dan menggolongkannya ke dalam empat kategori tingkah laku dalam menggunakan internet, yaitu Operational Internet Skill, Formal Internet Skill, Information Internet Skill, dan Strategic Internet Skill.

Learning Theory atau Teori Pembelajaran berisi tentang pengamatan proses belajar yang terjadi berupa interaksi yang terjadi, elemen-elemen yang terlibat dan tujuan dasar mengapa dilakukan sebuah pembelajaran. (Wati, 2010)memetakan teori tentang pembelajaran ke dalam tiga bagian besar, yaitu Teori belajar behavioristik, teori belajar kognitif, dan teori belajar humanistik. Teori belajar behavioristik berorientasi pada hasil yang dapat diukur dan diamati, sedangkan teori belajar kognitif menitikberatkan kepada bagaimana siswa belajar berdasarkan pengalaman yang telah diperoleh, serta teori belajar humanistik berusaha memahami tingkah laku dalam proses belajar dan bagaiman siswa memahami lingkungannya.

Berdasarkan Peraturan Pemerintah Nomor 19 Tahun (2005) tentang Standar Pendidikan Nasional, menyatakan bahwa standar penilaian pendidikan adalah standar nasional pendidikan yang berkaitan dengan mekanisme, prosedur, dan instrumen penilaian hasil belajar peserta didik. Selanjutnya berdasarkan Peraturan Pemerintah Nomor 19 Tahun (2005) Pasal 25 bahwa standar kompentensi lulusan digunakan sebagai pedoman penilaian dalam penentuan kelulusan peserta didik dalam satuan pendidikan, sedangkan standar kompetensi lulusan mencakup sikap, pengetahuan dan keterampilan. Sedangkan berdasarkan Peraturan Menteri Pendidikan Nasional Nomor 20 Tahun (2007) tentang Standar Penilaian Pendidikan, menyatakan bahwa penilaian hasil belajar oleh pedidik dilakukan secara berkesinambungan, bertujuan untuk memantau proses dan kemajuan belajar peserta didik serta untuk meningkatkan efektivitas kegiatan pembelajaran.

Optimisasi menurut (Rao, 1995) adalah tindakan untuk memperoleh hasil terbaik atau tepat sasaran dalam keadaan-keadaan tertentu. Keputusan yang diambil merupakan sebuah keputusan yang berupa meminimalkan upaya yang diperlukan atau untuk memaksimalkan manfaat yang diinginkan sehingga mendapatkan nilai maksimum atau minimum dari setiap variabel yang diputuskan. Sedangkan menurut Yuwono (2007) menjelaskan optimalisasi dapat ditempuh dengan dua cara yaitu maksimalisasi dan minimalisasi. Maksimalisasi adalah optimalisasi produksi dengan menggunakan atau mengalokasian input yang sudah tertentu untuk mendapatkan keuntungan yang maksimal. Sedangkan minimalisasi adalah optimalisasi produksi untuk menghasilkan tingkat output tertentu dengan menggunakan input atau biaya yang paling minimal. Jadi, secara umum optimalisasi merupakan proses maksimalisasi atau minimalisasi sesuai dengan batas-batas, ketentuan, target atau harapan yang ingin dicapai.

Berdasarkan penelitian terdahulu yang dikemukakan oleh (Isracezwendy, 2012), (Bagir, 2006), dan (Widiatmika, 2007), dijelaskan bahwa terdapat pengaruh penggunaan internet dan laboratorium komputer terhadap peningkatan prestasi belajar siswa. Oleh karena itu, pada penelitian ini dibuat strategi optimalisasi untuk memaksimalkan pengaruh penggunaan internet tersebut terhadap peningkatan pretasi belajar, dalam artian penggunaan internet dijadikan sebuah cara, metode, dan bahkan best practices dalam model pembelajaran untuk meningkatkan prestasi belajar. 
Dalam buku yang berjudul Business Analysis, dijelaskan bahwa definisi popular dari strategi adalah arah dan cakupan organisasi dalam jangka panjang, yang dapat memberikan pencapaian keuntungan bagi organiasi melalui pengaturan sumber daya dalam lingkungan yang terus berubah dan untuk memenuhi harapan stakeholder(Paul, Yeates, \& Cadle, 2010). Di dalam penelitian ini, perumusan strategi menggunakan analisis SWOT (Strength, Weakness, Opportunity, Threat), yang mana strategi-strategi yang diperoleh merupakan kombinasi dari aspek eksternal yaitu Opportuniy (Peluang) dan Threat (Ancaman), dengan aspek internal yaitu Strength (Kekuatan) dan Weakness (Kelemahan). Aspek eksternal diperoleh dari hasil analisis lingkungan eksternal menggunakan analisis PEST (Politic, Economic, Social, Technology). Sedangkan aspek internal diperoleh dari hasil analisis lingkungan internal menggunakan analisis tekstual berdasarkan hasil wawancara, observasi, dan review dokumen.

Berdasarkan teori-teori yang telah dipaparkan di atas, maka dibuat sebuah Theoretical Framework yang merupakan kerangka kerja yang menggambarkan secara umum pembuatan strategi optimalisasi penggunaan internet. Kerangka kerja penelitian ini mengadopsi kerangka kerja System Thinking.System Thinking merupakan suatu pendekatan menyeluruh dalam perencanaan strategis dan proses manajemen perubahan memfokuskan kepada hasil akhir dari suatu proses perubahan. Untuk setiap langkah-langkah yang diperlukan untuk mencapai hasil akhir proses perubahan tersebut, ditentukan juga faktor-faktor yang mempengaruhinya (Haines, 2000). Adapun Theoretical Framework penelitian ini adalah sebagai berikut:

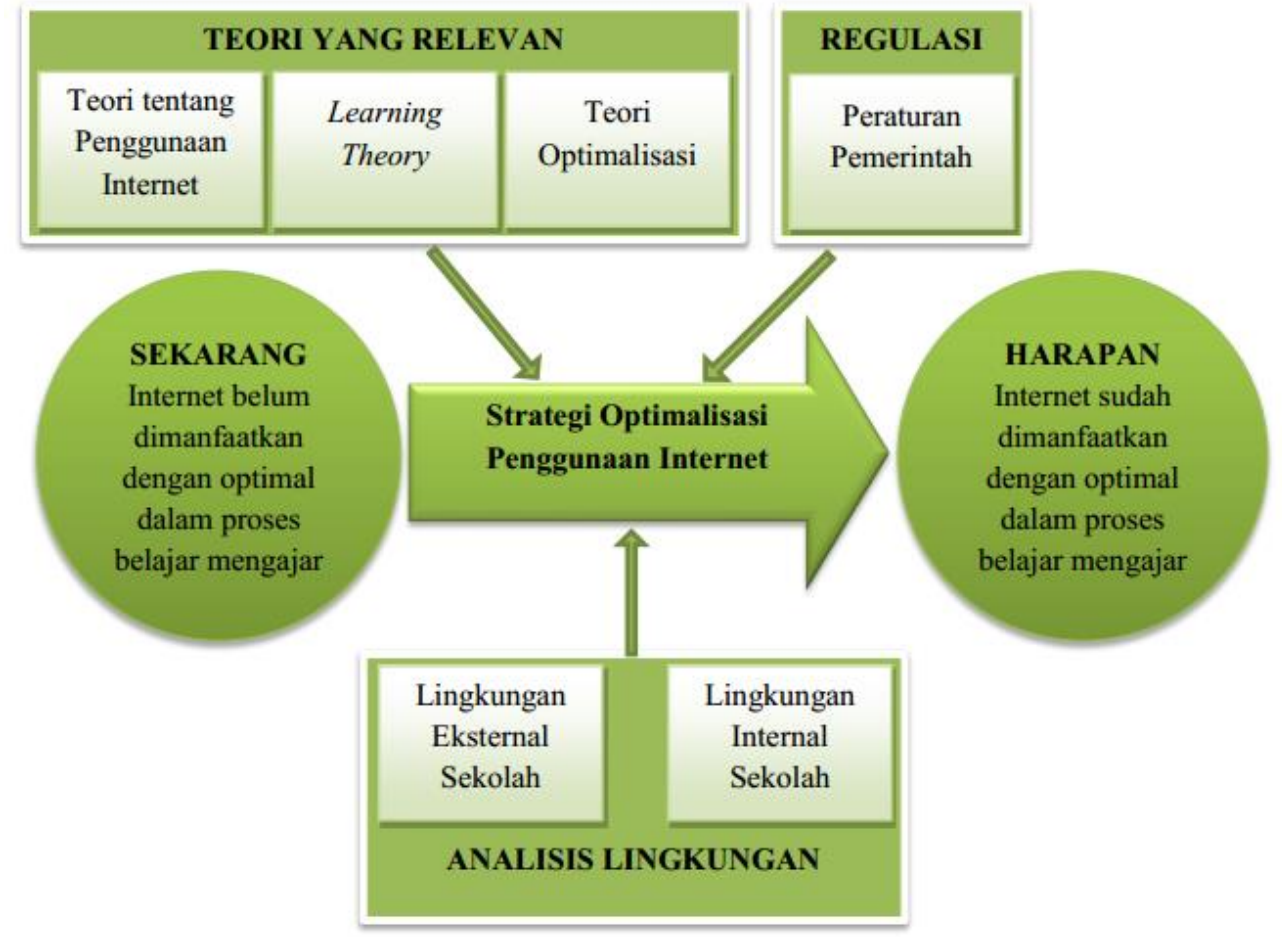

Gambar 1. Theoretical Framework

Gambar Theoretical Framework di atas menjelaskan tentang perumusan strategi optimalisasi penggunaan internet yang didasari pada kondisi sekarang dimana internet belum dimanfaatkan dengan optimal dalam proses belajar mengajar di sekolah, maka diperlukan strategi optimalisasi penggunaan internet untuk 
mencapai kondisi yang diharapkan dimana internet telah dimanfaatkan dengan optimal dalam proses belajar mengajar di sekolah. Perumusan strategi ini dibentuk oleh beberapa teori yang relevan yang mendukung yaitu teori tentang penggunaan internet, teori pembelajaran, teori optimalisasi, serta regulasi atau peraturanperaturan pemerintah yang menjadi tolok ukur standar penilaian sekolah dan tujuan dari model pembelejaran dengan menggunakan teknologi informasi. Selain itu diperlukan juga analisis lingkungan mengenai kondisi lingkungan eksternal dan internal sekolah. Kondisi yang diharapkan setelah perumusan strategi ini adalah internet sudah dimanfaatkan dengan optimal dalam proses belajar mengajar sehingga dapat meningkatkan prestasi belajar siswa sesuai dengan standar atau mutu yang dicanangkan sekolah.

\section{METODE PENELITIAN}

Metodologi penelitian ini disusun untuk menjawab pertanyaan dan tujuan penelitian. Jenis penelitian ini menurut tujuan merupakan Applied Research karena penelitian ini diarahkan untuk mendapatkan informasi yang dapat digunakan untuk memecahkan masalah yang terjadi. Kemudian, berdasarkan teknik pengumpulan datanya, penelitian ini diklasifikasikan ke dalam penelitian kualitatif karena digunakan untuk mendapatkan data yang lebih mendalam, suatu data yang mengandung makna sehingga dalam penelitian kualitatif lebih menekankan makna dari pada generalisasi. Sedangkan jenis penelitian ini menurut metode merupakan Policy Research karena proses penelitian yang dilakukan pada analisis terhadap masalah-masalah sosial yang mendasar, sehingga temuannya dapat direkomendasikan kepada pembuat keputusan untuk bertindak dalam menyelesaikan masalah. Selanjutnya dalam Policy Reseacrh, penelitian ini digolongkan kedalam Policy Making karena keluaran dari penelitian ini adalah berupa strategi pemecahan masalah yang terjadi. Kemudian, metodologi penelitian ini akan diuraikan ke dalam beberapa langkah-langkah penelitian yaitu sebagai berikut:

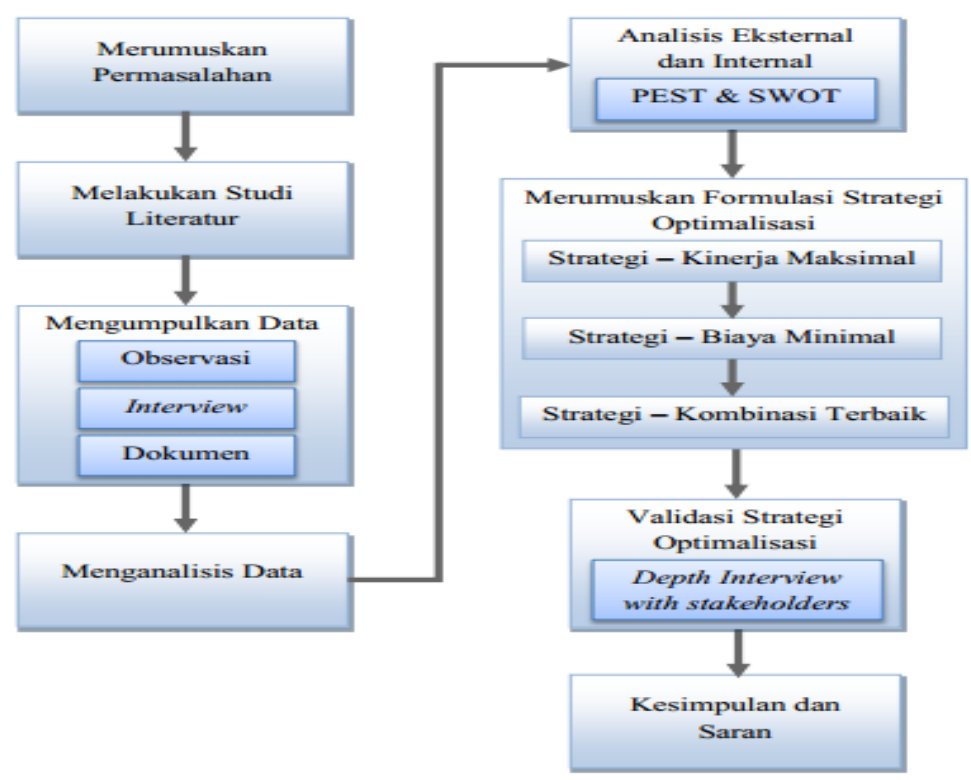

Gambar 2. Diagram Alir Penelitian 
Gambar di atas menunjukkan penelitian ini dibuat berdasarkan permasalahan yang terjadi di lokasi penelitian. Permasalahan tersebut tentang rendahnya prestasi belajar siswa yang diliat dari kurang optimalnya dalam penggunaan internet sebagai media pembelajaran. Berdasarkan permasalahan tersebut, maka dilakukan studi literatur untuk mengetahui teori-teori yang relevan tentang penggunaan internet sebagai penunjang dalam peningkatan prestasi belajar siswa. Kemudian dilakukan pengumpulan data-data yang terkait dengan permasalahan yang ada, dan menganalisisnya sesuai dengan teori yang ada. Kemudian melalukan analisis keadaan lingkungan sekolah. Analisis ekstenal menggunakan analisis PEST dan analisis internal menggunakan analisis tekstual, sedangkan analisis SWOT digunakan untuk merumuskan strategi optimalisasi penggunaan internet. Hasil dari analisis kemudian diteruskan dalam formulasi strategi optimalisasi. Hasil strategi strategi optimalisasi dipetakan ke dalam tiga kategori yaitu strategi optimalisasi berdasarkan pencapaian kinerja maksimal, strategi optimalisasi berdasarkan penggunaan biaya minimal, dan kombinasi terbaik dari pencapaian kinerja maksimal dan penggunaan biaya minimal. Untuk hasil strategi yang baik, maka dilakukan validasi strategi optimalisasi keseluruhan melalui depth interview dengan stakeholders atau pemangku kepentingan di sekolah sehingga menghasilkan keluaran sesuai dengan harapan dan kemampuan sekolah dalam mengimplementasikannya. Tahap terakhir adalah membuat kesimpulan dan saran pada penelitian ini.

\section{HASIL PENELITIAN}

Hasil dari penelitian adalah strategi optimalisasi penggunaan internet yang akan dapat digunakan dalam model pembelajaran, sehingga bermanfaat dalam peningkatan prestasi belajar siswa. Adapun hasil perumusan strategi-strategi optimalisasi tersebut adalah sebagai berikut:

Tabel 2. Strategi Optimalisasi Peggunaan Internet

\begin{tabular}{|l|l|}
\hline Kode & Strategi Optimalisasi \\
\hline S1 & Membuat model pembelajaran -learning \\
\hline S2 & $\begin{array}{l}\text { Mempertahankan dan memperkuat dukungan dari manajemen pihak sekolah dan } \\
\text { pemerintah }\end{array}$ \\
\hline S3 & Mempertahankan dan memperkuat hubungan dengan orang tua siswa \\
\hline S4 & Membuat pelatihan tentang Teknologi Informasi dan Komunikasi \\
\hline S5 & Mewajibkan untuk setiap guru mata pelajaran untuk memperbaharui materi bahan ajar \\
\hline S6 & $\begin{array}{l}\text { Memberdayakan guru untuk menggunakan media pembelajaran dalam proses belajar } \\
\text { mengajar }\end{array}$ \\
\hline S7 & Melengkapi dan memperbaiki fasilitas Lab. Komputer \\
\hline S8 & Menganjurkan akses Lab. Komputer kapanpun sepanjang jam sekolah \\
\hline S9 & Memberikan bantuan alat pendidikan bagi siswa yang kurang mampu \\
\hline S10 & $\begin{array}{l}\text { Memaksimalkan penggunan website sekolah sebagai sarana informasi sekolah dan } \\
\text { informasi bahan ajar }\end{array}$ \\
\hline S11 & Mengajukan proposal bantuan untuk penambahan gedung RKB \\
\hline S12 & Mempercepat pelaporan permohonan bantuan untuk kelengkapan fasilitas \\
\hline S13 & Menekankan untuk setiap warga sekolah untuk menjaga fasilitas-fasilitas sekolah \\
\hline S14 & Melakukan perawatan secara intensif terhadap fasilitas TI \\
\hline S15 & Mengawasi siswa dalam penggunaan internet di sekolah \\
\hline S16 & Membentuk kegiatan-kegiatan pengembangan karakter siswa \\
\hline S17 & $\begin{array}{l}\text { Meningkatkan pengawasan dan memberikan fokus utama terhadap peredaran narkoba dan } \\
\text { pornografi }\end{array}$ \\
\hline S18 & $\begin{array}{l}\text { Memberikan selalu sosialisasi dan peringatan akan dampak negatif dari narkoba dan } \\
\text { pornografi }\end{array}$ \\
\hline
\end{tabular}




\begin{tabular}{|l|l|}
\hline Kode & Strategi Optimalisasi \\
\hline S19 & Membentuk klub-klub ekstrakurikuler untuk mengembangkan bakat dan minat siswa \\
\hline S20 & Memberikan sanksi yang tegas dan jelas kepada siswa yang tidak berperilaku baik \\
\hline S21 & Membuat grup-grup belajar dalam media sosial \\
\hline
\end{tabular}

Ada 21 strategi optimalisasi yang diperoleh berdasarkan hasil analisis SWOT yang dilakukan. Hasil strategi yang telah diperoleh kemudian dipetakan ke dalam tiga kategori yaitu kategori berdasarkan pencapaian kinerja maksimal, kategori berdasarkan penggunaan biaya minimal dan kategori berdasarkan kombinasi terbaik dari pencapaian kinerja maksimal dan penggunaan biaya minimal. Dalam pengkategorisasiannya berdasarkan penilaian yang dilakukan oleh stakeholders yang dipilih dari pihak sekolah, yaitu Kepal Sekolah, Wakil Kepala Sekolah bidang Kurikulum, Wakil Kepal Sekolah bidang Kesiswaan, Koordinator Laboratorium Komputer, dan salah satu guru senior dan berprestasi di sekolah ini. Adapun hasil pemetaannya adalah sebagai berikut:

1) Strategi optimalisasi penggunaan internet berdasarkan pencapaain kinerja maksimal menghasilkan strategi-strategi sebagai berikut:

a) Membuat model pembelajaran e-learning

b) Membuat pelatihan tentang Teknologi Informasi dan Komunikasi

c) Mewajibkan untuk setiap guru mata pelajaran untuk memperbaharui materi bahan ajar

d) Memberdayakan guru untuk menggunakan media pembelajaran dalam proses belajar mengajar

e) Memberikan bantuan alat pendidikan bagi siswa yang kurang mampu

f) Memaksimalkan penggunan website sekolah sebagai sarana informasi sekolah dan informasi bahan ajar

g) Melakukan perawatan secara intensif terhadap fasilitas TI

h) Mengawasi siswa dalam penggunaan internet di sekolah

i) Membentuk kegiatan-kegiatan pengembangan karakter siswa

j) Membentuk klub-klub ekstrakurikuler untuk mengembangkan bakat dan minat siswa

k) Membuat grup-grup belajar dalam media sosial

2) Strategi optimalisasi penggunaan internet berdasarkan penggunaan biaya minimal menghasilkan strategi-strategi sebagai berikut:

a) Mempertahankan dan memperkuat dukungan dari manajemen pihak sekolah dan pemerintah

b) Mempertahankan dan memperkuat hubungan dengan orang tua siswa

c) Menganjurkan akses Lab. Komputer kapanpun sepanjang jam sekolah

d) Menekankan untuk setiap warga sekolah untuk menjaga fasilitas-fasilitas sekolah

e) Mengawasi siswa dalam penggunaan internet di sekolah

f) Meningkatkan pengawasan dan memberikan fokus utama terhadap peredaran narkoba dan pornografi

g) Memberikan selalu sosialisasi dan peringatan akan dampak negatif dari narkoba dan pornografi

h) Membentuk klub-klub ekstrakurikuler untuk mengembangkan bakat dan minat siswa

i) Memberikan sanksi yang tegas dan jelas kepada siswa yang tidak berperilaku baik 
j) Membuat grup-grup belajar dalam media sosial

3) Strategi optimalisasi penggunaan internet berdasarkan kombinasi terbaik dari pencapaian kinerja maksilam dan penggunaan biaya minimal menghasilkan strategi-strategi sebagai berikut:

a) Mengawasi siswa dalam penggunaan internet di sekolah

b) Membentuk klub-klub ekstrakurikuler untuk mengembangkan bakat dan minat siswa

c) Membuat grup-grup belajar dalam media sosial

Strategi optimalisasi penggunaan internet yang menjadi rekomendasi terbaik ke pihak sekolah dalam rangka meningkatkan prestasi belajar melalui penggunaan internet adalah strategi yang ada dalam poin ketiga, karena ketiga strategi tersebut memiliki kriteria nilai terbaik dengan nilai optimal untuk semua strategi dalam pencapain kinerja dan penggunaan biaya.

\section{PEMBAHASAN}

Perumusan strategi optimalisasi menggunakan analisis SWOT. Strategi yang diperoleh berdasarkan kombinasi dari aspek eksternal dan internal dalam analisis SWOT. Aspek ekternal diperoleh dari hasil analisis eksternal sekolah menggunakan analisis PEST. Fakta-fakta eksternal yang diperoleh berdasarkan hasil wawancara dan observasi serta analisi dokumen-dokumen terkait. Selanjutnya fakta-fakta eksternal sekolah dipetakan ke dalam empat aspek, yaitu aspek Politik, Ekonomi, Sosial, dan Teknologi, kemudian mengklasifikasikannya ke dalam faktor peluang atau ancaman terhadap sekolah berdasarkan analisis dampak yang ditimbulkan terhadap sekolah. Sedangkan aspek internal diperoleh dari hasil analisis internal sekolah menggunakan analisis Tekstual. Fakta-fakta internal yang diperoleh juga berdasarkan hasil wawancara, observasi, dan menganalisis dokumen-dokumen terkait. Fakta-fakta internal yang diperoleh kemudian dianalisis berdasarkan empat kategori, yaitu berdasarkan studi literatur yang dilakukan, melihat standar yang berlaku, meminta pendapat dari para pakar, dan melihat kompetitor-kompetitor dari sekolah lain. Wawancara dilakukan kepada Kepala Sekolah, Wakil Kepala Sekolah bidang Kurikulum, dan Koordinator Laboratorium Komputer sekaligus merupakan salah satu guru mata pelajaran. Penentuan strategi optimalisasi ini juga diperkuat dengan teori-teori yang dijabarkan pada studi literatur. Teori-teori tersebut akan menjadi dasar argumen dan memperkuat pemilihan atau penentuan strategi-strategi optimalisasi. Adapun hasil analisis SWOT penelitian ini adalah sebagai berikut:

Tabel 3. Analisis SWOT

\begin{tabular}{|l|l|ll|l|}
\hline & \multicolumn{2}{|c|}{ Kekuatan (Strength) } & \multicolumn{2}{c|}{ Kelemahan (Weakness) } \\
\hline & K1. & Dukungan dari manajemen & L1. Kualitas SDM rendah \\
& sekolah & & L2. Sarana dan Prasarana \\
& K2. & Struktur organisasi yang & kurang lengkap \\
& jelas & & L3. Kebijakan tidak jelas \\
& K3. & Standar disiplin yang tinggi & tentang penggunaan internet \\
& K4. & Anggaran pendidikan yang & L4. Kurangnya pelatihan \\
& jelas & & L5. Motivasi belajar siswa \\
& & & rendah \\
& & & L6. Kurangnya buku-buku \\
& & & referensi Variasi metode \\
& & & L7. \\
& & &
\end{tabular}




\begin{tabular}{|c|c|c|c|}
\hline & & Kekuatan (Strength) & Kelemahan (Weakness) \\
\hline 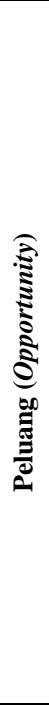 & $\begin{array}{l}\text { P1. Dukungan dari } \\
\text { pemerintah daerah } \\
\text { P2. Peminat yang } \\
\text { banyak } \\
\text { P3. Kerja sama yang } \\
\text { baik antara pihak sekolah dan } \\
\text { orang tua siswa } \\
\text { P4. Pastisipasi aktif } \\
\text { dari alumni pada setiap } \\
\text { kegiatan sekolah } \\
\text { P5. Perkembangan } \\
\text { TIK sangat pesat }\end{array}$ & $\begin{array}{l}\text { KP1. Membuat model } \\
\text { pembelajaran } \text {-learning }(\mathrm{K} 1, \mathrm{P} 5) \text {. } \\
\text { KP2. Mengawasi siswa dalam } \\
\text { penggunaan internet di sekolah (K1, K3, } \\
\text { P5) } \\
\text { KP3. Mempertahankan dan } \\
\text { memperkuat dukungan dari manajemen } \\
\text { sekolah dan pemerintah (K1, P1). } \\
\text { KP4. Mempertahankan dan } \\
\text { memperkuat hubungan dengan orang tua } \\
\text { siswa (K1, P3). } \\
\text { KP5. Mengajukan proposal } \\
\text { bantuan untuk penambahan gedung } \\
\text { RKB (K1, K4, P2). } \\
\text { KP6. Membentuk kegiatan- } \\
\text { kegiatan pengembangan karakter siswa } \\
\text { (K1, K3, P4). }\end{array}$ & $\begin{array}{l}\text { LP1. Membuat pelatihan } \\
\text { tentang TIK (L1, L4 P1, P5). } \\
\text { LP2. Mewajibkan setiap guru } \\
\text { mata pelajaran untuk selalu } \\
\text { memperbaharui bahan ajar (L1, L3, } \\
\text { L6, P5) } \\
\text { LP3. Melengkapi dan } \\
\text { memperbaiki fasilitas laboratorium } \\
\text { komputer (L2, L3, L5, L6, L7, P2, } \\
\text { P5). } \quad \text { Memaksimalkan } \\
\text { LP4. } \quad \text { penggunaan website sekolah } \\
\text { sebagai sarana informasi sekolah } \\
\text { dan bahan ajar (L3, L5, L6, P2, P5). } \\
\text { LP5. Memberdayakan guru } \\
\text { untuk menggunakan media } \\
\text { pembelajaran dalam proses belajar } \\
\text { mengajar (L1, L3, L6, L7, P5). } \\
\text { LP6. Membentuk klub-klub } \\
\text { ekstrakurikuler untuk } \\
\text { mengembangkan bakat dan minat } \\
\text { siswa (L5, L7, P1, P3, P4, P5). }\end{array}$ \\
\hline 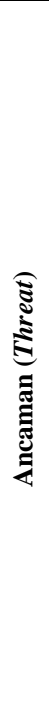 & 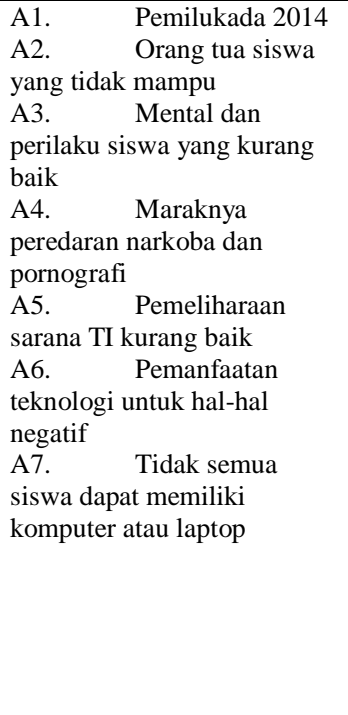 & $\begin{array}{l}\text { KA1. Memberikan bantuan alat } \\
\text { pendidikan bagi siswa yang kurang } \\
\text { mampu (K1, K4, A2, A7). } \\
\text { KA2. Menekankan kepada setiap } \\
\text { warga sekolah untuk selalu menjaga } \\
\text { fasilitas-fasilitas sekolah (K1, K2, K3, } \\
\text { A5) } \\
\text { KA3. Mempercepat pelaporan } \\
\text { permohonan bantuan untuk kelengkapan } \\
\text { fasilitas (K1, A1, A5). } \\
\text { KA4. Menganjurkan akses Lab. } \\
\text { Komputer kapanpun sepanjang jam } \\
\text { sekolah (K1, A2, A7). } \\
\text { KA5. Meningkatkan pengawasan } \\
\text { dan memberikan fokus utama terhadap } \\
\text { peredaran narkoba dan pornografi (K1, } \\
\text { K3, A4). } \\
\text { KA6. Memberikan sanksi yang } \\
\text { tegas dan jelas kepada siswa yang } \\
\text { perilaku baik (K3, A3, A6). }\end{array}$ & $\begin{array}{l}\text { LA1. Melakukan perawatan } \\
\text { secara intensif terhadap fasilitas TI } \\
\text { (L2, L3, A5) } \\
\text { LA2. Menekankan kepada } \\
\text { seluruh warga sekolah pentingnya } \\
\text { fasilitas TI dan penggunaanya (L2, } \\
\text { A5, A6) } \\
\text { LA3. Melakukan pelatihan } \\
\text { tentang TIK (L1, A6) } \\
\text { LA4. Membentuk klub-klub } \\
\text { ekstrakurikuler sesuai dengan bakat } \\
\text { dan minat siswa (L5, L7, A3, A6) } \\
\text { LA5. Memberikan selalu } \\
\text { sosialisasi dan peringatan akan } \\
\text { dampak negatif dari narkoba dan } \\
\text { pornografi (L1, L5, A4, A6) } \\
\text { LA6. Menyelenggarakan } \\
\text { kegiatan untuk membentuk karakter } \\
\text { siswa yang baik (L1, L5, A3). } \\
\text { LA7. Membuat grup-grup } \\
\text { belajar dalam media sosial (L2, L3, } \\
\text { A6). }\end{array}$ \\
\hline
\end{tabular}

Berdasarkan hasil analisi SWOT tersebut, maka diperoleh 21 strategi optimalisasi penggunaan internet. Strategi-strategi tersebut diperoleh berdasarkan kombinasi dari aspek eksternal yaitu peluang dan ancaman dengan aspek internal yaitu kekuatan dan kelemahan. Dalam penentuan strategi-strategi tersebut, juga memperhatikan teori-teori yang telah dijabarkan sebagai dasar argumen dan memperkuat pemilihan strategi-strategi tersebut.

Strategi optimalisasi yang telah diperoleh kemudian akan dipetakan ke dalam tiga kategori, yaitu strategi optimalisasi berdasarkan pencapaian kinerja maksimal, strategi optimalisasi berdasarkan penggunaan biaya minimal, dan strategi optimalisasi berdasarkan kombinasi terbaik dari pencapain kinerja maksimal dan penggunaan biaya minimal. Pemetaan ini dilakukan berdasarkan penilian yang dilakukan oleh pihak sekolah. Stakeholders yang terlibat ke dalam tim penilaian adalah Kepala Sekolah. Wakil Kepala Sekolah bidang Kurikulum, Wakil Kepala Sekolah bidang Kesiswaan, Koordinator Laboratorium Komputer, dan salah satu guru berprestasi di sekolah ini. Stakeholders yang terpilih layak terlibat ke dalam penilaian karena kesemuanya merupakan saksi sejarah akan perkembangan sekolah 
ini sehingga tahu tentang kondisi sekolah sepenuhnya. Adapun hasil penilaiannya dapat dilihat sebagai berikut:

Tabel 4. Pemetaan Strategi Optimalisasi Penggunaan Internet

\begin{tabular}{|c|c|c|c|c|}
\hline Kode & Strategi Optimalisasi & Tujuan/Dampak/Manfaat & Kinerja & Biaya \\
\hline S1 & $\begin{array}{l}\text { Membuat model pembelajaran } \\
\text { e-learning }\end{array}$ & $\begin{array}{l}\text { Memaksimalkan sumber daya } \\
\text { yang dimiliki }\end{array}$ & $80 \%$ & High \\
\hline S2 & $\begin{array}{l}\text { Mempertahankan dan } \\
\text { memperkuat dukungan dari } \\
\text { manajemen pihak sekolah dan } \\
\text { pemerintah }\end{array}$ & $\begin{array}{l}\text { Mendapatkan kemudahan dalam } \\
\text { setiap perubahan yang akan } \\
\text { dilakukan }\end{array}$ & $70 \%$ & Low \\
\hline S3 & $\begin{array}{l}\text { Mempertahankan dan } \\
\text { memperkuat hubungan dengan } \\
\text { orang tua siswa }\end{array}$ & $\begin{array}{l}\text { Mendapatkan kemudahan dalam } \\
\text { pengawasan terhadap siswa di } \\
\text { luar sekolah }\end{array}$ & $70 \%$ & Low \\
\hline $\mathrm{S} 4$ & $\begin{array}{l}\text { Membuat pelatihan tentang } \\
\text { Teknologi Informasi dan } \\
\text { Komunikasi }\end{array}$ & $\begin{array}{l}\text { Meningkatkan kompetensi SDM } \\
\text { tentang TIK }\end{array}$ & $80 \%$ & Medium \\
\hline S5 & $\begin{array}{l}\text { Mewajibkan untuk setiap guru } \\
\text { mata pelajaran untuk } \\
\text { memperbaharui materi bahan } \\
\text { ajar }\end{array}$ & $\begin{array}{l}\text { Menyesuaikan topik pembahasan } \\
\text { dalam materi pelajaran sesuai } \\
\text { dengan keadaan terkini }\end{array}$ & $80 \%$ & Medium \\
\hline S6 & $\begin{array}{l}\text { Memberdayakan guru untuk } \\
\text { menggunakan media } \\
\text { pembelajaran dalam proses } \\
\text { belajar mengajar }\end{array}$ & $\begin{array}{l}\text { Membuat variasi model } \\
\text { pembelajaran yang kondusif }\end{array}$ & $80 \%$ & Medium \\
\hline S7 & $\begin{array}{l}\text { Melengkapi dan memperbaiki } \\
\text { fasilitas Lab. Komputer }\end{array}$ & $\begin{array}{l}\text { Memfasilitasi siswa dalam } \\
\text { pemenuhan kebutuhan akan } \\
\text { informasi }\end{array}$ & $80 \%$ & High \\
\hline S8 & $\begin{array}{l}\text { Menganjurkan akses Lab. } \\
\text { Komputer kapanpun sepanjang } \\
\text { jam sekolah }\end{array}$ & $\begin{array}{l}\text { Memfasilitasi siswa dalam } \\
\text { pemenuhan kebutuhan akan } \\
\text { informasi }\end{array}$ & $70 \%$ & Low \\
\hline S9 & $\begin{array}{l}\text { Memberikan bantuan alat } \\
\text { pendidikan bagi siswa yang } \\
\text { kurang mampu }\end{array}$ & $\begin{array}{l}\text { Melakukan pemerataan } \\
\text { penggunana sumber daya dalam } \\
\text { proses belajar mengajar }\end{array}$ & $80 \%$ & High \\
\hline $\mathrm{S} 10$ & $\begin{array}{l}\text { Memaksimalkan penggunan } \\
\text { website sekolah sebagai sarana } \\
\text { informasi sekolah dan informasi } \\
\text { bahan ajar }\end{array}$ & $\begin{array}{l}\text { Memfasilitasi siswa dalam } \\
\text { pemenuhan kebutuhan akan } \\
\text { informasi }\end{array}$ & $80 \%$ & Medium \\
\hline $\mathrm{S} 11$ & $\begin{array}{l}\text { Mengajukan proposal bantuan } \\
\text { untuk penambahan gedung RKB }\end{array}$ & $\begin{array}{l}\text { Menambah daya tampung sesuai } \\
\text { dengan kondisi sumber daya } \\
\text { manusia yang ada }\end{array}$ & $70 \%$ & Medium \\
\hline S12 & $\begin{array}{l}\text { Mempercepat pelaporan } \\
\text { permohonan bantuan untuk } \\
\text { kelengkapan fasilitas }\end{array}$ & $\begin{array}{l}\text { Menghindari jadwal-jadwal sibuk } \\
\text { dari pihak birokrasi }\end{array}$ & $60 \%$ & Medium \\
\hline S13 & $\begin{array}{l}\text { Menekankan untuk setiap warga } \\
\text { sekolah untuk menjaga fasilitas- } \\
\text { fasilitas sekolah }\end{array}$ & $\begin{array}{l}\text { Mendapatkan kenyamanan } \\
\text { penggunaan fasilitas sekolah }\end{array}$ & $70 \%$ & Low \\
\hline S14 & $\begin{array}{l}\text { Melakukan perawatan secara } \\
\text { intensif terhadap fasilitas TI }\end{array}$ & $\begin{array}{l}\text { Mendapatkan kenyamanan } \\
\text { penggunaan fasilitas sekolah }\end{array}$ & $80 \%$ & Medium \\
\hline S15 & $\begin{array}{l}\text { Mengawasi siswa dalam } \\
\text { penggunaan internet di sekolah }\end{array}$ & $\begin{array}{l}\text { Meningkatkan pemahaman siswa } \\
\text { dalam berpikir dan bertindak }\end{array}$ & $80 \%$ & Low \\
\hline S16 & $\begin{array}{l}\text { Membentuk kegiatan-kegiatan } \\
\text { pengembangan karakter siswa }\end{array}$ & $\begin{array}{l}\text { Mengembangkan pendidikan } \\
\text { berkarakter }\end{array}$ & $80 \%$ & Medium \\
\hline S17 & $\begin{array}{l}\text { Meningkatkan pengawasan dan } \\
\text { memberikan fokus utama } \\
\text { terhadap peredaran narkoba dan } \\
\text { pornografi }\end{array}$ & $\begin{array}{l}\text { Meningkatkan pemahaman siswa } \\
\text { dalam berpikir dan bertindak }\end{array}$ & $70 \%$ & Low \\
\hline
\end{tabular}




\begin{tabular}{|c|l|l|c|c|}
\hline S18 & $\begin{array}{l}\text { Memberikan selalu sosialisasi } \\
\text { dan peringatan akan dampak } \\
\text { negatif dari narkoba dan } \\
\text { pornografi }\end{array}$ & $\begin{array}{l}\text { Meningkatkan pemahaman siswa } \\
\text { dalam berpikir dan bertindak }\end{array}$ & $70 \%$ & Low \\
\hline S19 & $\begin{array}{l}\text { Membentuk klub-klub } \\
\text { ekstrakurikuler untuk } \\
\text { mengembangkan bakat dan } \\
\text { minat siswa }\end{array}$ & $\begin{array}{l}\text { Meningkatkan motivasi atau } \\
\text { minat belajar siswa }\end{array}$ & $80 \%$ & Low \\
\hline S20 & $\begin{array}{l}\text { Memberikan sanksi yang tegas } \\
\text { dan jelas kepada siswa yang } \\
\text { tidak berperilaku baik }\end{array}$ & $\begin{array}{l}\text { Meningkatkan pemahaman siswa } \\
\text { dalam berpikir dan bertindak }\end{array}$ & $60 \%$ & Low \\
\hline S21 & $\begin{array}{l}\text { Membuat grup-grup belajar } \\
\text { dalam media sosial }\end{array}$ & $\begin{array}{l}\text { Meningkatkan motivasi atau } \\
\text { minat belajar siswa }\end{array}$ & $80 \%$ & Low \\
\hline
\end{tabular}

Berdasarkan tabel di atas, maka dapat dilihat bahwa nilai pencapaian kinerja optimal adalah $80 \%$ dari pencapaian nilai optimum $100 \%$. Sedangkan penggunaan biaya optimal masuk ke dalam kategori Low, yang mana juga merupakan nilai optimum dalam penggunaan biaya minimal.

\section{KESIMPULAN}

Seperti yang telah diuraikan pada tahap Pendahuluan, pertanyaan penelitian ini adalah "Bagaimanakah Strategi Optimalisasi Penggunaan Internet terhadap Peningkatan Prestasi Belajar Siswa ?" dengan tujuan spesifik yaitu membuat strategi penggunaan internet tersebut. Berdasarkan analisis yang dilakukan, maka dapat ditarik kesimpulan sebagai berikut:

1) Peningkatan prestasi belajar siswa melalui penggunaan internet secara dapat dicapai melalui 21 (dua puluh satu) strategi optimalisasi. Strategi yang diusulkan antara lain berkaitan dengan pembuatan model pembelajaran, perbaikan fasilitas, pengawasan, dan penggunaan sumber daya yang tersedia secara optimal.

2) Perumusan strategi ini menggunakan analisis SWOT untuk menganalisis lingkungan eksternal dan internal sekolah dan mengidentifikasikan empat kekuatan, tujuh kelemahan, lima peluang dan tujuh ancaman yang menggambarkan kondisi lingkungan SMA Negeri 1 Burau.

3) Strategi optimalisasi ini dipetakan ke dalam tiga kategori utama tentang optimalisasi, yaitu kategori strategi optimalisasi berdasarkan pencapaian kinerja maksimal menghasilkan sebelas strategi, kategori strategi optimalisasi berdasarkan penggunaan biaya minimal menghasilkan sepuluh strategi, dan kategori strategi optimalisasi berdasarkan kombinasi terbaik dari pencapaian kinerja dan penggunaan biaya menghasilkan tiga strategi yaitu:

a) Mengawasi siswa dalam penggunaan internet di sekolah

b) Membentuk klub-klub ekstrakurikuler untuk mengembangkan bakat dan minat siswa

c) Membuat grup-grup belajar dalam media sosial

4) Kajian sistematis secara ilmiah terbukti dapat menjawab masalah praktis yang dihadapi oleh sebuah organisasi, dalam studi kasus ini adalah SMA Negeri 1 Burau. Beberapa pelajaran yang dipelajari selama penelitian ini akan dijabarkan dalam subbab saran 


\section{SARAN}

Berikut saran-saran yang diberikan agar strategi-strategi optimalisasi yang telah disusun dalam penelitian ini dapat berjalan dengan baik, serta saran untuk penelitian selanjutnya. (1) Melaksanakan strategi-strategi optimalisasi tersebut dengan mengetatkan pengawasan dengan menentukan Person in Charge (PIC) untuk setiap strategi optimalisasi tersebut pada tahap-tahap awal pengimplementasiannya karena pada tahap-tahap awal merupakan titik rawan akan gagalnya implementasi strategi tersebut; (2) Melakukan evaluasi secara rutin untuk memastikan bahwa strategi-strategi optimalisasi tersebut telah dijalankan sesuai dengan yang diharapkan dan berjalan terus menerus sesuai dengan kondisi dan arah kebijakan sekolah; (3) Perlu diadakan penelitian lebih lanjut mengenai bagaimana penerapan model pembelajaran e-learning yang baik dan kondusif untuk meningkatkan prestasi belajar siswa pada tingkat sekolah menengah atas (SMA).

\section{DAFTAR PUSTAKA}

Ajie, M. D. (2008). Internet dan World Wide Web, Sejarah dan Perkembangannya.

Bagir, M. (2006). Pengaruh Kesiapan Sekolah, Sumber Daya Manusia dan Pemeliharaan dan Perawatan terhadap Optimalisasi Fungsi Laboratorium Komputer Sekolah: Studi Kasus Pada Madrasah Aliyah. Jakarta: FasilkomUI.

Haines, S. (2000). The System Thinking Approach to Strategic Planning and Management. St. Lucie Press.

Horrigan, J. B. (2002). New Internet Users: What They Do Online, What They Don't, and Implications for The 'Net's Future.

Isracezwendy, R. (2012). Pengaruh Penggunaan Internet terhadap Peningkatan Prestasi Belajar Siswa tingkat SMA/MA di Jakarta: Studi Kasus Madrasah Aliyah Citra Cendekia. Jakarta: Fasilkom-UI.

Paul, D., Yeates, D., \& Cadle, J. (2010). Business Analysis 2nd Edition. British Informatics Society Limited.

Peraturan Pemerintah Republik Indonesia Nomor 19 tentang Standar Nasional Pendidikan. (2005).

Peraturan Menteri Pendidikan Nasional Republik Indonesia Nomor 20 tentang Standar Penilaian Pendidikan. (2007).

Quarterman, J., \& Mitchell, S. C. (1996). What is The Internet, Anyway? IETF RFC 1935.

Rao, S. S. (1995). Engineering Optimization Theory and Practice 3rd Edition. New York: John Wiley and Sons, Inc.

Van Deursen, A., \& Van Dijk, J. (2009). Using The Internet: Skill Related Problems in User's Online Behavior.

Wati, W. (2010). Teori Belajar dan Pembelajaran. Padang: Program Pasca SarjanaUNP.

Widiatmika, I. (2007). Pengembangan Model Penerimaan Teknologi Internet oleh Pelajar dengan Menggunakan Konsep Technology Acceptance Model (TAM). Jakarta: Fasilkom-UI.

Yuwono, B. (2007). Bahan Kuliah Riset Operasional. Yogyakarta: Teknik Informatika-UPN. 